\title{
PENGARUH EFIKASI DIRI TERHADAP KINERJA PNS GURU SMAN WILAYAH II JAKARTA PUSAT
}

\author{
Rohman Hidayatul Attoriq \\ Prodi Pendidikan Guru Madrasah Ibtidaiyah, Fakultas Agama Islam, Universitas \\ Nahdlatul Ulama Indonesia (UNUSIA) \\ E-mail: rohmanhidayat@unusia.ac.id
}

\begin{abstract}
Article Information
Informasi Artikel

Naskah diterima:

Maret 2020

Naskah direvisi:

September 2020

Naskah disetujui:

Seprember 2020

Naskah dipublish: 15

Oktober 2020

Abstrak

The objective of this research is to obtain information

9 about the effect of self efficacy on performance. It was quantitative research with survey method in SMA $\mathrm{N}$

17 region II Central Jakarta. The research was conducted to all civil servant teachers by using a survey method with

21 path analysis applied in testing hypothesis. The number 117 civil servant teachers as sample was selected by using 5 Slovin formula. The research conlude: There is a direct positive effect of self efficacy on performance.
\end{abstract}

\section{PENDAHULUAN}

Kinerja para guru sebagai sumber daya manusia di sekolah merupakan salah satu tolak ukur tinggi rendahnya kualitas pendidikan, pendidikan dinyatakan berkualitas apabila guru mengacu pada visi, misi, tujuan, sasaran pendidikan yang disusun untuk menjawab perubahan dengan menggerakkan potensi sumber daya yang ada dalam lembaga pendidikan. Tercapainya sasaran pendidikan yang dimaksud tidak akan bisa terlaksana tanpa adanya seorang guru yang berkualitas.

Kualitas guru harus benar-benar merepresentasikan figur manusia yang bukan hanya mampu mengajar tetapi mendidik dengan memberi contoh kongkret dalam kehidupan sosial. Oleh karena itu guru merupakan salah satu faktor penentu tinggi rendahnya mutu hasil pendidikan dan mempunyai posisi strategis maka setiap usaha peningkatan mutu pendidikan perlu memberikan perhatian besar kepada peningkatan guru terutama dalam hal kinerjanya.

Kinerja guru pada dasarnya merupakan kegiatan guru dalam melaksanakan tugas dan kewajibannya sebagai seorang pengajar dan pendidik di sekolah yang dapat menggambarkan mengenai prestasi kerjanya dalam melaksanakan semua itu, dan hal ini jelas bahwa pekerjaan sebagai guru tidak bisa dilakukan oleh sembarang orang, tanpa memiliki keahlian, kompetensi yang mumpuni. Seorang guru dapat dikatakan 
memiliki kompetensi paling tidak memiliki empat kompetensi utama yakni: kompetensi pedagogik, kompetensi kepribadian, kompetensi sosial, kompetensi professional. Guru dapat dikatakan profesional adalah guru yang memiliki profesional capasity yakni memiliki kemampuan intelegensi, sikap, nilai, dan keterampilan serta prestasi dalam pekerjaannya. Secara sederhana, guru harus menguasai materi yang diajarkan. Guru yang menguasai materi akan memiliki kepercayaan diri dalam menyampaikan materi tersebut. Sehingga hal tersebut dapat mendorong kualitas kinerja dari seorang guru.

Kualitas kinerja guru dapat ditinjau dari segi proses dan segi hasil. Dari segi proses guru dikatakan berhasil apabila mampu melibatkan sebagian besar peserta didik secara aktif, baik fisik, mental, maupun sosial dalam proses pembelajaran. Di samping itu dapat dilihat juga dari gairah dan semangat mengajarnya serta adanya percaya diri yang tinggi dalam menjalankan tugas-tugas pembelajaran yang diberikan. Dari segi hasil, guru dikatakan berhasil apabila pembelajaran yang dilakukan mampu mengubah perilaku sebagian besar peserta didik ke arah penguasaan kompetensi dasar.

Ditengah asumsi tentang kualitas kinerja dan mutu guru, muncul kritik terhadap kualitas dan mutu guru. Merujuk pada hasil uji kompetensi guru 2014, lebih 1,3 juta guru dari total 1,6 juta guru yang mengikuti uji kompetensi ternyatamemiliki nilai ujian di bawah 60 dari rentang 0-100. Hampir 130.000 guru memperoleh nilai antara 0 dan 30. Mereka umumnya lemah dalam penguasaan materi ajar dan kemampuan mendidik.

Rendahnya kinerja guru juga diindikasikan dengan kurangnya administrasi guru, seperti malas membuat silabus dan RPP, guru mengajar di kelas tanpa ada persiapan tentang metode dan strategi penyampaian materi yang akan diajarkan. Selain itu minimnya aktifitas pembelajaran yang dapat memunculkan daya kreativitas dan kemampuan berfikir kritis peserta didik hal ini disebabkan guru tidak dapat menerapkan metode pembelajaran yang aktif, kreatif, inovatif dan menyenangkan.

Berkenaan dengan rendahnya kinerja guru Dinas Pemerintah DKI Jakarta yang disampaikan oleh Kepala Dinas Pendidikan DKI Jakarta memberikan sanksi kepada 13 guru yang dinilai memiliki kinerja buruk. Banyaknya guru yang memiliki kinerja buruk ini ditengarai oleh rendahnya efikasi diri. Memperhatikan kondisi-kondisi yang telah dipaparkan diatas, peneliti memandang perlunya dikaji tentang pengaruh efikasi diri terhadap kinerja guru SMAN wilayah II Jakarta Pusat. 


\section{METODE PENELITIAN}

Penelitian ini dilaksanakan di SMAN Wilayah II Jakarta Pusat. Pendekatan penelitian dilakukan secara kuantitatif, dengan metode survey, diukur menggunakan instrumen kuisioner. Analisis data menggunakan statistik parametris dengan path analysis. Penelitian ini dilaksanakan kepada seluruh PNS guru SMAN Wilayah II Jakarta Pusat yang berjumlah 169 guru dengan jumlah sampel 117 guru. Data dikumpulkan dengan menggunakan instrumen berupa kuisioner yang telah diuji validitas dan reliabilitasnya. Berdasarkan hasil uji instrumen tersebut, variabel kinerja terdiri dari 30 item pernyataan valid dengan reliabilitas 0,934 . Variabel efikasi diri terdiri 31 item pernyataan valid dengan reliabilitas 0,947. Sehingga disimpulkan memenuhi syarat untuk dijadikan pengukur variabel penelitian.

\section{KAJIAN TEORI}

\section{Kinerja}

Kinerja dalam bahasa Inggris dikenal dengan istilah performance yaitu hasil kerja yang dicapai seorang pegawai atau unjuk kerja yang ditampilkan pegawai dalam kegiatan sehari-hari. Sejalan dengan definisi tersebut menurut Colquitt, "job performance is formally defined as the value of the set of employee behaviors that contribute, either positively or negatif, to organizational goal accomplishment". Kinerja secara formal didefinisikan sebagai nilai dari perilaku pegawai yang berkontribusi baik secara positif maupun negatif, untuk pencapaian tujuan organisasi. Kinerja merupakan hasil kerja seseorang dalam menyelesaikan tugas-tugas yang dibebankan kepadanya sesuai dengan perannya dalam sebuah organisasi. Sehingga dapat dikatakan bahwa tolak ukur dari keberhasilan sebuah organisasi adalah tergantung pada sejauhmana kualitas kinerja dari pegawainya.

Lebih lanjut Colquitt menambahkan, job performance has three dimensions: task performance, citizenship behavior, and counterproductive behavior. Kinerja mempunyai tiga dimensi yaitu perilaku tugas, perilaku sukarela dan perilaku menantang. Ketiga dimensi tersebut merupakan dimensi yang umumnya terdapat pada kinerja. 
Jhon R. Schermerhorn ${ }^{1}$ mengatakan bahwa, "job performance is measured as the quantity and quality of tasks accomplished by an individual or group." Kinerja dapat diukur dari kuantitas dan kualitas tugas yang dipenuhi oleh individu atau kelompok.Ini menunjukkan bahwa kinerja atau prestasi kerja secara kualitas dan kuantitas kerja yang dicapai oleh seorang karyawan dalam melaksanakan tugasnya sesuai dengan tanggung jawab yang diberikan.

Lebih lanjut Kinicki dan Kreitner" menjelaskan bahwa, "preference for working on tasks of moderate difficulty (2) a preferance for situations in which performance is due to their efforts rather than other factors, such as luck, and (3) they desire more feedback on their successes and failures than do low achievers". Ketiga karakter tersebut adalah : (1) menyukai pekerjaan yang tugas-tugasnya mengandung kesulitan, (2) menyukai situasi dimana kinerja merupakan hasil dari usaha, bukan faktor-faktor lain seperti keberuntungan, dan (3) mengharapkan hasil dari kesuksesan dan kegagalan. Dari penjelasan di atas dapat dimaknai bahwa seorang karyawan dapat dikatakan memiliki kinerja yang baik apabila paling tidak memiliki salah satu dari ketiga karakter tersebut, misalnya dalam hal menyukai pekerjaan, seorang pekerja bila sudah menyukai pekerjaan maka seberapa sulit tugas tersebut akan dikerjakanya dengan sepenuh hati sehingga hasil yang dikerjakanya pun akan jauh lebih maksimal daripada karyawan yang melakukan tugas pekerjaan dengan terpaksa.

Sedangkan menurut James L. Gibson, et, al "job performance is the outcomes of jobs that relate to the purposes of the organization such as quality, efficiency, and other criteria of effectiveness". Kinerja merupakan hasil dari pekerjaan yang berhubungan dengan tujuan organisasi seperti kualitas, efisiensi dan kriteria kriteria lain dari efektifitas. Craig C. Pinder menambahkan bahwa, "job performance is the accomplishment of work related goals, regardless of the means of their accomplishment". Kinerja adalah prestasi pencapaian tujuan kerja dengan keberhasilan prestasi mereka. Kinerja merupakan tolak ukur dari keberhasilan suatu organisasi,

\footnotetext{
${ }^{1}$ Schermerhorn, John R, et. al, (2010). Organizational Behavior. New Jersey: John Wiley, hal 308-309 ${ }^{2}$ Kreitner, Robert dan Kinicki, Angelo. (2010). Organizational Behavior. New York: McGraw-Hill, hlm 150

${ }^{3}$ Gibson, James, et.al. (2012).Organizations: Behavior, Structure, Processes 14th Ed. New York: McGraw-Hill,hlm:374
} 
dengan kinerja yang baik seluruh target pekerjaan dapat terselesaikan dengan baik pula.

Berdasarkan uraian di atas, dapat disintesiskan kinerja adalah perilaku pegawai yang berkontribusi terhadap pencapaian tujuan organisasi sesuai dengan perannya dalam melaksanakan tugas dengan indikator : kesediaan pegawai untuk melakukan tugas rutin, kesediaan pegawai untuk melakukan tugas sukarela, kualitas dalam pelaksanaan kerja, dan efektivitas dalam pelaksanaan kerja.

\section{Efikasi Diri}

Efikasi diri pertama kali diperkenalkan oleh Albert Bandura ${ }^{4}$ dengan teori kognitif sosialnya. Ia mendefinisikan efikasi diri adalah "perceived self-efficacy is definiting as people's beliefs about their capabilities to produce designated levels of performance that exercise influence over events that effect their lives. Self-efficacy beliefs determine how people feel, think, motivate themselves and behave. Such beliefs produce these diverseeffects through four major processes. They include cognitive, motivational, affective and selection processes". Efikasi diri merupakan suatu keyakinan seseorang mengenai kemampuan yang dimilikinya untuk menghasilkan tingkatan performa yang telah terencana, dimana kemampuan tersebut telah terlatih oleh kejadian-kejadian yang berpengaruh terhadap hidupnya. Keyakinan tersebut menentukan bagaimana seseorang merasa, berpikir, dan memotivasi dirinya untuk bertindak. Selain itu juga mempengaruhi empat proses utama, yaitu proses kognisi, motivasional, afeksi, dan proses seleksi.

Pendapat lain mengenai efikasi diri juga dikemukakan oleh Luthans ${ }^{5}$ menyatakan bahwa, "self-efficacy is the perception or belief of the individual that he or she can successfully accomplish a specific task, and it is associated with goal commitment". Pendapat Luthans menjelaskan bahwa efikasi diri adalah persepsi atau keyakinan individu bahwa ia dapat berhasil menyelesaikan tugas tertentu, dan hal ini berhubungan dengan komitmen tujuan. Individu yang memiliki efikasi diri yang tinggi ia akan merasa yakin dan mampu dan berhasil dalam menjalankan tugas-tugas yang

\footnotetext{
${ }^{4}$ Bandura, Albert. (1977). Self-Efficacy in Changing Societies. NewYork. Cambridge University Press.

${ }^{5}$ Johnston, Robert E and Bate, Jr. J. Douglas. (2003). Strategy Innovation a New Way of Linking Creativity and Strategic Planning to Discover Great Business Opportunitie. New York: Amacom.
} 
diberikan terhadap dirinya yang kemudian hal ini juga berhubungan dengan komitmen tujuan.

Philips ${ }^{6}$ menambahkan bahwa, "general self-eficacy is your generalized belief that you will be successful at whatever challenges or tasks you might lace". Efikasi diri adalah keyakinan umum bahwa seseorang akan berhasil pada tantangan ataupun tugas yang sulit. Bagi seorang yang memiliki efikasi diri yang tingi seberapa sulitpun tugas yang diberikan kepadanya ia tidak akan mudah menyerah karena sudah tertanam dalam pikiranya bahwa ia mampu mengerjakan tugas sulit tersebut.

Sedangkan menurut Stephen P. Robbins dan Mary Cuolter" bahwa, "selfefficacy is an individual's belief that he or she is capable of performing a task". Efikasi diri merupakan keyakinan individu bahwa ia mampu melakukan tugas. Berdasar keyakinan tersebut individu dapat memanfaatkan secara optimal setiap pengetahuan dan keterampilan untuk melaksanakan tugas dan mencapai tujuannya. Keyakinan yang kuat atas kemampuan diri akan menentukan kegigihan, ketekunan dan keuletan dalam melaksanakan tugas atau mencapai tujuan.

Berdasarkan deskripsi konsep di atas dapat disintesiskan efikasi diri adalah keyakinan diri seseorang tentang kemampuannya untuk melaksanakan tugas tertentu dalam rangka mencapai keberhasilan dengan indikator : dapat melaksanakan tugas dengan sukses, meliliki percaya diri yang tinggi, memiliki tingkat motivasi yang tinggi, dan dapat mengatasi kesulitan tugas.

\section{PENGUJIAN PERSYARATAN ANALISIS}

Pengujian analisis yang dilakukan adalah

\section{1) Uji Normalitas}

Dari hasil perhitungan diperoleh nilai $\mathrm{L}_{\text {hitung }}=0,0803$ nilai ini lebih kecil dari nilai $\mathrm{L}_{\text {tabel }}(\mathrm{n}=117 ; \alpha=0,05)$ sebesar 0,082. Mengingat nilai $\mathrm{L}_{\text {hitung }}$ lebih kecil dari $\mathrm{L}_{\text {tabel }}$ maka sebaran data kinerja atas efikasi diri cenderung membentuk kurva normal.

\section{2) Uji Signifikansi dan Lineaeritas Koefisien Regresi}

Dari data hasil perhitungan untuk penyusunan model persamaan regresi antara

\footnotetext{
${ }^{6}$ Charnpoux, JosephE. (2011). Organizational Behavior. New York: Rounledge

${ }^{7}$ Robbins, Stephen P dan Judge, Timothy A. (2013). Organizational Behavior 15th Ed. New Jersey: Pearson, hlm:436
} 
kinerja dengan efikasi diri pada lampiran 5 diperoleh konstanta regresi a $=81,02$ dan koefisien regresi $b=0,32$. Dengan demikian hubungan model persamaan regresi sederhana adalah $\mathrm{Y}=81,02+0,32 \mathrm{X}_{1}$.

\section{HASIL PERHITUNGAN UJI SIGNIFIKANSI DAN LINEARITAS}

Tabel 4.5

ANAVA untuk Uji Signifikansi dan Linearitas Persamaan Regresi $\mathrm{Y}=\mathbf{8 1 , 0 2}+\mathbf{0 , 3 2 X _ { 1 }}$

\begin{tabular}{|c|c|c|c|c|c|c|}
\hline \multirow{2}{*}{ Sumber Varians } & \multirow{2}{*}{$\mathbf{d k}$} & \multirow{2}{*}{ JK } & \multirow{2}{*}{ RJK } & \multirow{2}{*}{$F_{\text {hitung }}$} & \multicolumn{2}{|c|}{$F_{\text {tabel }}$} \\
\hline & & & & & $\alpha=0,05$ & $\alpha=\mathbf{0 , 0 1}$ \\
\hline Total & $\begin{array}{c}11 \\
7\end{array}$ & 1693080 & & & & \\
\hline Regresi a & 1 & $\begin{array}{c}1686720,5 \\
5\end{array}$ & & & & \\
\hline Regresi b/a & 1 & 902,34 & $\begin{array}{c}902,3 \\
4\end{array}$ & $19,02 * *$ & 3,92 & 6,86 \\
\hline Residu & $\begin{array}{c}11 \\
5\end{array}$ & 5457,11 & 47,45 & & & \\
\hline $\begin{array}{l}\text { Tuna Cocok } \\
\text { Galat }\end{array}$ & $\begin{array}{l}36 \\
79 \\
\end{array}$ & $\begin{array}{l}1871,59 \\
3585,51 \\
\end{array}$ & $\begin{array}{l}51,99 \\
45,39 \\
\end{array}$ & $1,15^{\mathrm{ns}}$ & 1,57 & 1,88 \\
\hline
\end{tabular}

Untuk uji signifikansi diperoleh $F_{\text {hitung }} 19,02$ lebih besar dari pada $F_{\text {tabel }(0,01 ; 1: 115)}$ 6,86 pada $\alpha=0,01$. Karena $F_{\text {hitung }}>F_{\text {tabel }}$ maka persamaan regresi dinyatakan sangat signifikan. Untuk uji linearitas diperoleh $\mathrm{F}_{\text {hitung }}$ sebesar 1,15 lebih kecil dari pada $F_{\text {tabel }(0,05 ; 36: 79)}$ sebesar 1,57 pada $\alpha=0,05$. Karena $F_{\text {hitung }}<F_{\text {tabel }}$ maka sebaran titik yang terestimasi membentuk garis linear dapat diterima.

\section{Pengujian Hipotesis}

Efikasi diri berpengaruh langsung positif terhadap kinerja.

$$
\begin{aligned}
& \mathrm{H}_{0}: \beta_{31} \leq 0 \\
& \mathrm{H}_{1}: \beta_{31}>0
\end{aligned}
$$

$\mathrm{H}_{0}$ ditolak, jika $\mathrm{t}_{\text {hitung }}>\mathrm{t}_{\text {tabel. }}$.

Dari hasil perhitungan analisis jalur, pengaruh langsung efikasi diri terhadap kinerja, nilai koefisien jalur sebesar 0,280 dan nilai $t_{\text {hitung }}$ sebesar 3,11. Nilai $t_{\text {tabel }}$ untuk $\alpha=0,01$ sebesar 2,62 . Oleh karena nilai $t_{\text {hitung }}$ lebih besar dari pada nilai $t_{\text {tabel }}$ maka dengan demikian $\mathrm{H}_{0}$ ditolak dan $\mathrm{H}_{1}$ diterima yaitu bahwa efikasi diri berpengaruh secara langsung positif terhadap kinerja dapat diterima. 
Hasil analisis hipotesis pertama memberikan temuan bahwa efikasi diri berpengaruh secara langsung positif terhadap kinerja. Dengan demikian dapat disimpulkan bahwa kinerja dipengaruhi secara langsung positif oleh efikasi diri. Meningkatnya efikasi diri mengakibatkan peningkatan kinerja.

\section{PENGARUH EFIKASI DIRI TERHADAP KINERJA}

Dari hasil pengujian hipotesis pertama dapat disimpulkan bahwa terdapat pengaruh langsung positif efikasi diri terhadap kinerja dengan nilai koefisien korelasi sebesar 0,377 dan nilai koefisien jalur sebesar 0,280. Ini memberikan makna efikasi diri berpengaruh langsung terhadap kinerja.

Hasil penelitian ini senada dengan pendapat beberapa ahli diantaranya adalah pendapat Jennifer M. George dalam bukunya bahwa, "self-efficacy can have such powerful effects on learning and performance in organization, it is important to identify where it come from". Efikasi diri dapat memiliki pengaruh yang sangat siknifikan terhadap pembelajaran dan kinerja dalam organisasi, hal ini penting untuk mengidentifikasi di mana asalnya. Guru yang mengetahui asal dan tujuan tentang tugas mereka sebagai pendidik maka ia akan menjalankan tugas-tugasnya dalam mendidik secara sepenuh hati dan dengan penuh keyakinan bahwa profesi yang ia jalani adalah yang akan menghatarkan kepada kesuksesan dalam hidup sehingga guru tersebut akan lebih meningkatkan kinerjanya.

Hal senada juga diungkapkan James L Gibson and Jhon M. Ivancevich ${ }^{8}$ ia mengatakan bahwa, "a concept that has potential effect on self-efficacy is the pygmalion effect, which refers to enhanced learning or performance that result from others having positive expectation of us. That is the fact that others believe us capable of high level of performance may lead us to perform at that level". Sebuah konsep yang memiliki efek potensial pada efficacy diri adalah efek Pygmalion. Efek Pygmalion yang dimaksud adalah jika guru memiliki efikasi diri yang tinggi terhadap kemampuanya maka ia akan berfikir positif terhadap tugas-tugasnya sehingga ia akan mampu menampilkan kinerja terbaiknya di sekolah.

\footnotetext{
${ }^{8}$ Gibson, James, et.al. (2012).Organizations: Behavior, Structure, Processes 14th Ed. New York: McGraw-Hill.
} 
Lebih lanjut Stephen Robbins and Timothy A Judge ${ }^{9}$ mengatakan, "self efficacy can create a positive spiral which those with high efficacy become more engaged in their tasks and then in turn increase performance, which increase efficacy further". Efikasi diri dapat membuat ikatan positif diamana guru yang memiliki efikasi yang tinggi akan lebih terlibat dalam tugas-tugas mereka dan kemudian pada giliranya dapat meningkatkan kinerja.

Jhon B. Miner menambahkan bahwa, "in the goal setting view, self-efficacy raises the level of set goal, reinforces commitment to these goals, and thus enhances the level of performance”. Dalam melihat penetapan tujuan, efikasi diri menaikkan tingkat penetapan tujuan, memperkuat komitmen untuk tujuan-tujuan ini, dan dengan demikian meningkatkan tingkat kinerja. Dengan efikasi diri yang tinggi sesorang guru akan mengerti dan memahami tujuan dari sebuah organisasi sehingga mereka sehingga akan bermuara pada peningkatan kinerja mereka . Berdasarkan uraian di atas, maka efikasi diri berpengaruh positif secara langsung terhadap kinerja.

\section{KESIMPULAN}

Berdasarkan hasil dan analisis data, maka dapat diambil kesimpulan: (1) efikasi diri berpengaruh langsung positif terhadap kinerja. Artinya, peningkatan efikasi diri mengakibatkan peningkatan kinerja PNS Guru SMAN Wilayah II Jakarta Pusat. Berdasarkan kesimpulan di atas, maka saran yang perlu ditindak lanjuti antara lain:

1. Guru hendaknya memiliki kepercayaan diri dan keyakinan terhadap kemampuan yang dimilikinya dalam melaksanakan tugas-tugas pembelajaran dan tidak mudah menyerah dan putus asa saat menghadapi masalah.

2. Bagi kepala sekolah dan dinas terkait agar memberikan fasilitas pembelajaran yang memadai khususnya media pembelajaran yang berbasis multi media dan mengadakan pelatihan-pelatihan serta seminar secara intensif guna meningkatkan kompetensi yang dimiliki para guru sehingga dapat meningkatkan efikasi diri para guru dalam menunjang kinerjanya di sekolah.

\footnotetext{
${ }^{9}$ Robbins, Stephen P dan Judge, Timothy A. (2013). Organizational Behavior 15th Ed. New Jersey: Pearson
} 


\section{DAFTAR PUSTAKA}

Alice White, Margaret and Bruton, Garry D. (2011). The Management of Technology and innovation : a Strategic Approach. South Westrem: Cengage Learnig.

Bandura, Albert. (1977). Self- Efficacy in Changing Societies. NewYork. Cambridge University Press.

Charnpoux, Joseph E. (2011). Organizational Behavior. New York: Rounledge.

Colquitt, Jason A, Lepine , Jeffery A., dan Wesson, Michael J. (2011). Organizational Behavior. NewYork: McGraw-Hill.

Gibson, James, et.al. (2012).Organizations: Behavior, Structure, Processes 14th Ed. New York: McGraw-Hill.

Jeschke, Sabina, and Hees Frank. (2013). Automation, Comunication and Cybernetics in Science and Engineering. Berlin: Springer Verlag.

Johnston, Robert E and Bate, Jr. J. Douglas. (2003). Strategy Innovation a New Way of Linking Creativity and Strategic Planning to Discover Great Business Opportunitie. New York: Amacom.

Kreitner, Robert dan Kinicki, Angelo. (2010). Organizational Behavior. New York: McGraw-Hill.

Locke, Edwin A. and Latham, Gary P. (2013). New Developments in Goal Setting and Task Performance. New York : Routledge.

Moorhead and Griffin. (2014). Organizational Behavior. South Western: Cengage Learning.

Robbins, Stephen P dan Judge, Timothy A. (2013). Organizational Behavior 15th Ed. New Jersey: Pearson.

Schermerhorn, John R, et. al, (2010). Organizational Behavior. New Jersey: John Wiley.

Slocum, John W dan Hellriegel, Don. (2011). Organizational Behavior 13th Ed. Mason: South Western. 